\title{
The Different Changes Of Value Relevance Of Earnings Between SOEs And NSOEs After Adoption Of IFRS: Evidence From China
}

\author{
Wanli Li, Xi'an Jiaotong University, China
}

Hong Guo, Xi'an Jiaotong University, China

\begin{abstract}
This article studies changes of value relevance of earnings after mandatory adoption of new CAS (the Chinese Accounting Standards) which is substantially convergent with IFRS (the International Financial Report Standards) in China's listed enterprises. We extend the previous research by examining the different impact on value relevance of earnings between SOEs (the State-Owned Enterprises) and NSOEs (the Non-State-Owned Enterprises) after adoption of new CAS, which is based on the samples consisting of 836 companies listed on A-shares market of China. The empirical results show that the value-relevance of accounting earnings significantly increased after 2007, and represent that value relevance of earnings increased significantly in SOEs while there are no significant changes in NSOEs after adoption of the new CAS. Our research has implications for China's Accounting Standard setters who desire to reach expected consequences of convergence with IFRS, and provide empirical evidence for adoption of IFRS in different countries which have both SOEs and NSOEs.
\end{abstract}

Keywords: Value Relevance of Earnings; IFRS Convergence; China; SOEs

\section{INTRODUCTION}

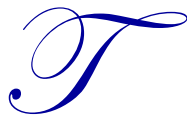
he economic internationalization and the globalization of markets are pressed for international convergence of accounting standards. In fact, more than 100 countries and regions have adopted International Financial Reporting Standards (IFRS) in various ways. The IFRS was expected to provide more "transparency and comparability of financial statements" (European Communities 2002: Art 1). But, some scholars such as Soderstrom \& Sun (2007) suggest that a set of standards may not be suitable for all settings. After all, IFRS originated from English language countries with developed economies. So, it is necessary to "have an understanding of the impact of IFRS as they are adopted in particular regions" (The International Accounting Standards Board [IASB], 2004, Para. 93). In fact, on the applicability of IFRS to other countries, many studies have examined it based on data from different countries, such as German (Jermakowicz, Prather-Kinsey, and Wulf, 2007), UK (Horton and Serafeim, 2010), Norway (Gjerde, Knivsfla, and Saettan, 2008), and so on.

China, which becomes more and more important for the world economy, has proceeded a series of reformation on accounting standards in the past 30 years. As a result, in 2006, the Ministry of Finance of China issued the new Chinese Accounting Standards (CAS) which is more convergent with IFRS than all the previous versions of CAS. And in 2012, CAS has been equivalent with IFRS, therefore, the accounting reports complying with CAS were equal to the accounting reports complying with IFRS, and were accepted in European market. Ding \& Su (2008) suggest that adoption of IFRS in China provides direct evidence on whether IFRS can play the expected role in regulating markets. Recently, some related researches have studied on whether adoption of IFRS have achieved expected target as providing more "transparency and comparability of financial statements" in China (He, Wong \& Young, 2012; Liu, Yao, Hu and Liu, 2011) 
Nevertheless, to the best of our knowledge, there are few researches have taken notice of the difference changes of accounting quality between state-owned and non-state-owned enterprises after the adoption of IFRS in China. China, which has changed the planned economics system into an emerging market economy, has some unique characteristics, for example, most of all listed companies in China have higher level of ownership concentration than those in the West or other developed market. Furthermore, On Chinese stock market, there are two types of listed enterprises, one type is state-owned enterprises (SOEs) which are hold by central government, local government or state asset management bureaus (which is controlled by the central government or the local government), and SOEs is the majority of the stock market. The other type is non-state-owned enterprises (NSOEs) which hold by private. Many researchers realize that different ownerships represent different incentives on controlling a company's management ( Shleifer and Vishny,1986; Morck, Shleifer, \& Vishney, 1989; Tirole, 2001). Daske, Hail, Leuz, \& Verdi (2008) find that enterprise's reporting incentive has an crucial effect on reporting result based on the research on mandatory IFRS reports all around the world, and Xiao, Weetman \& Sun (2004) show that except for economic and political factors, collectivism-oriented culture strengthens the incentive to comply with Standards. So, although SOEs and NSOEs operate in the same political, institutional, and economic environment, SOEs controlled by state are generally restructured from state enterprise and their senior managements are appointed by government, whereas, the NSOEs are generally controlled by private who have set up them. In view of the difference of controlling shareholder and senior management between SOEs and NSOEs, SOEs are generally more collectivistic than NSOEs. Moreover, Ding, Qu, and Zhuang (2011) provide evidence shows that Type I agency problems caused by the separation of management and ownership are alike in family firms and non-family firms in China, but, because of the existence of the controlling shareholders and weak legal protection on minority shareholders, Type II agency problems caused by controlling shareholders encroaching on the interests of minority shareholders are more serious in family firms than in non-family firms, and family firms are tended to provide less transparent financial reports which are against the purpose of IFRS. So, it is expected that respective investigation on SOEs' and NSOEs' value relevance changes after adoption IFRS have incremental contents.

Using a sample of all Chinese listed firms from 2004 to 2009, firstly, we examine the changes of value-relevance of accounting earnings based on all the listed firms after the adoption of IFRS on January 1, 2007, and find the valuerelevance of accounting earnings significantly increased after 2007. Then, we categorized the total sample into two groups of SOEs and NSOEs, and respectively examine the two groups. We find the SOEs' value-relevance of accounting earnings significantly increased, however, the NSOEs' value-relevance of accounting earnings have no significantly increase. Our results remain robust across different methods, samples and variables.

This study makes several contributions to the literature. Firstly, we extend the literature about whether earnings quality has improved with the adoption of IFRS and examine the changes of earnings quality with compulsory adoption in China. Liu et al. (2011) find earnings quality has significantly increased with the adoption of IFRS based on the samples from 2005 to 2008 . He et al. (2012) find the adoption of IFRS has increased the opportunity for managerial to manage earnings with traded-securities and debt restructuring, their study is based on the samples from 2007 to 2008. Our study extended the event period to a longer time and provided a more complete view of changes on earnings quality in China and results in improvement of value relevance of earnings and reduction of value relevance of book value which are different results from Liu et al. (2007). Secondly, this study distinguished the impact of different ownership on feasibility of IFRS for the first time. The coexistence of SOEs and NSOEs and the special status of SOEs that is different from the West and other developed markets provide us an opportunity to test the impacts of the different ownership on realizing expected goal of IFRS under the political, institutional, and economic environment.

The remainder of the article is organized as follows. Section 2 discusses China's institutional background. Section 3 reviews the related literature and develops the hypothesis. Section 4 discusses our sample and illustrates methods used to test the value-relevance of accounting earnings. Section 5 provides our analysis results and sensitivity test results. Section 6 concludes the article.

\section{INSTITUTIONAL BACKGROUND OF CHINA}

As a socialistic country, China ever practiced centrally planned economy for about 30 years from the founding of the country in 1949. But, with the economic reformation and opening up since 1978, China experienced a series of 
reformation on economic structure. The reformation of SOEs in 1980s and the establishments of the Shanghai and Shenzhen Stock Exchanges in the early 1990s indicated that the country was transforming to a socialistic market economy system and it gradually improved the system in the past 20 years. State enterprises, an important feature of China's centrally planned economy, were terminated the financial support, and became joint-stock enterprises with modern corporate system in 1990. As a matter of fact, state keeps control of the corporatization of state enterprises. In the early stages of the stock markets, most of the listed firms were SOEs. With the importance of private enterprises on economy dynamic growth being realization, the private enterprises have become increasingly significant in China's economy, so more and more private enterprises are publicly traded in stock market. China's stock market has experienced a rapid development since the establishment in 1990. According to statistical results of the Chinese Securities Regulatory Commission (CSRC), the market value of China's publicly traded shares was RMB23.036 billion, and the quantity of listed firms increased from 14 in 1990 to 2494 in 2012 ( from CSRC website). Just as Tan, Yang, and Veliyath (2007) state, centralized economy and its system have been replaced by market economy in the past 30 years.

In order to meet the demand of the emerging market economy and attracting foreign direct investment which is a way to achieve rapid economic growth (Wu, Boateng, \& Drury, 2007), CAS have experienced continuous changes from 1992 to 2006, and each version became more and more similar to IFRS. In fact, from the establishment of the People's Republic of China until early 1990s, there was no accounting standard and the systems of accounting followed the example of the former Soviet Union's accounting system which was appropriate for the centrally planned economy. On November 30, 1992, the Finance Ministry of China issued the first enterprises' accounting standards, and issued successively about 20 specific standards from May 22, 1997 to 2006, which marked the overall establishment of CAS. In February, 2006, the Finance Ministry of China issued the new CAS which revised the previous guidelines and added 16 specific standards. The new CAS is almost the same as IFRS apart from a little modification according to the national unified economic environment, and which results in the CAS being substantially convergent with IFRS.

In addition to the CAS, in the 30 years of economic reformation and opening up, China's enterprises has established the modern company system, and has established the similar corporate governance structure to that of the developed economy. However, China's listed companies have their unique characteristics. Firstly, the ownership structure is unique compared with those of other countries in the world. In China, there are six types of stocks: state shares, legal person shares, foreign shares, management shares, employee shares and individual shares. Although all shares have the same voting rights and cash flow rights (e.g. they are entitled to the same dividends), the ownership of the shares is restricted to certain types of investors (Firth, Fung, \& Rui, 2007), e.g. the state shares and the legal person shares cannot be traded in the free market. In the national stock market, SOEs are the main part. According to our statistics, private enterprises account for $32.01 \%$ in Chinese A shares of the motherboard market in 2013( the data is collected from Wind database), and equity proportion of foreign shares, management shares and employee shares is very small, which generally is respectively at around $1 \%$.

Secondly, Chinese enterprises generally have higher ownership concentration than that of the West. According to $\mathrm{Xu}$ (2004), most companies have a controlling shareholder whose ownership is $44 \%$ of its issued shares in average, and the second largest shareholder owns a 5\% stake in average. On June 12, 2001, the State Council issued a formal regulation of "reduction of state-owned shares to raise social security funds management procedures", which began to reduce the state-owned shares officially. After 10 years, among China's listed firms of A shares, the largest shareholder's equity ratio are $36.26 \%, 13.89 \%$ and $6.59 \%$ in average in 2013 . It shows that ownership concentration is still high in China's listed firms.

Thirdly, because of the second features, the impact of controlling shareholder on listed corporation is greater than that of the West, either in SOEs or NSOEs. In most circumstance, the actual controlling shareholders of SOEs are the central government, local government or State Management Department that is subject to the jurisdiction of the central government or local government. So, the state has a crucial influence on the appointment of listed corporation directors and top managements in SOEs. In many cases, the top management and directors of SOEs are the officials who are appointed by the government, and they are generally with the state administrative level. The ultimate controlling shareholders of China's private enterprise are often the first generation founders because China's private enterprises began to develop since 1980s (Ding et al., 2011). Under normal circumstances, they have 
a higher proportion of shareholding, and the most of them manage enterprises themselves, however, the founders and their heirs of private enterprises in the developed countries generally employ professional managers to manage the enterprises.

\section{RELEVANT LITERATURE AND HYPOTHESIS DEVELOPMENT}

As a global accounting standard (Chua \& Taylor, 2008), the influence of IFRS is rising in the world. However, IFRS is a standard based on the experience of UK and U.S. which are developed market-economy countries (Sunder, 2009; Tyrrall, Wookward, \& Rakhimbekova, 2007).It is still a hot issue whether IFRS can achieve its expected goals in different countries with different political and economic environments. Cormier, Dimaria, Lapointe-Antunes, and Teller (2009) show financial report quality of the French companies which adopted IFRS at the very beginning has improved significantly. After examining information comparability between 26 non-US companies and US companies from 1995 to 2006, Barth, Landsman, Lang, and Williams (2010) suggest that the value relevance and book value are more comparable between the two groups after the non-US companies adopting IAS (International Accounting Standards, the predecessor of IFRS). Yip and Young (2012) find the accounting earnings are more comparable in the industry from 17 different European countries after their mandatory adoption of IFRS in 2005. Li (2010) finds the cost of capital of the European countries is reduced after the mandatory adoption of IFRS. Wu and Zhang (2010) find European companies increase the using of accounting information of the foreign counterparts which has mandatorily adopted IFRS. However, there are some researches coming to the opposite conclusions. Bushman and Landsman (2010) suggest that the adoption of IFRS had the unexpected impact on the capital supervision of Spainish bank. Jeanjean and stolowy (2008) show that the pervasiveness of earnings management did not decrease, instead it increased after the introduction of IFRS in France. And Clarkson, Hanna, Richardson and Thompson (2011) find the adoption of IFRS have not improved quality of accounting financial reports based on the samples covering 14 countries in Europe and Australia.

Some studies have proved the changes of value relevance of accounting information after the adoption of IFRS or IAS. Barth, Landsman, Lang, and Williams (2006) show that value relevance of earnings has increased in companies from 21 countries after the adoption of IFRS. Capkun, Cazavan-Jeny, Jeanjean, and Weiss (2007) find earnings are value-relevant after local accounting standards and IFRS have harmonized based on a sample of 1772 companies from 9 European countries which were banned to adopt IFRS earlier. Horton and Serafeim (2010) find that accounting earnings are value-relevant after the coordination of IFRS in UK. Gjerde et al. (2008) find the coordination of GAAP to IFRS has marginal value relevance in Norway. Jermakowicz et al. (2007) find that value relevance of earnings has increased significantly after the adoption of IFRS in German. But, Goodwin, Ahmed and Heaney (2007) suggest that earnings and equity are not more value- relevant based on IFRS than those based on Australian GAAP.

Obviously, research conclusions are different from different countries, which indicate the impact of countries on the construction of financial reports. And the above researches are mainly for the developed countries. Recently, there are several related researches on China, a developing country, and they have resulted in different conclusions. Liu et al. (2011) find that earnings quality increased significantly after the adoption of IFRS based on 870 listed companies in China's stock market, as significant reduction of earnings management and significant improvement of value relevance of earnings. However, after studying the relation between fair value accounting and tradable securities and the relation between fair value accounting and debt restructuring, He et al. (2012) find that fair value becomes the means of earnings management after the issue of new CAS in 2006 which is substantial convergence with IFRS.

IFRS is a standard based on English language countries with developed economic, and Chiamisa (2000) suggests that IFRS is applicable in those countries similar to UK or US on national environment. Although China is a developing country, China's economy and society are more and more closer to the developed countries (Liu et al., 2011). So, Consistent with Liu et al. (2011), we suggest that IFRS can be applicable to China and it will improve the accounting information quality.

H1: value relevance of earnings would increase significantly after the adoption of IFRS in China. 
Because of the institutional characteristic, there are two types of listed enterprises with different ownership in China. One type is state-controlling enterprises transformed from state enterprises and the other type is private enterprises which started from 1980s and have experienced rapid development in the past 30 years, and the SOEs accounted for dominant percentage. Enterprises including SOEs and NSOEs are facing two types of agency problems. The first type resulting from the separation of ownership and management (Jensen and Meckling, 1976), are called Type I agency problems; the second type resulting from the confliction between controlling shareholders and noncontrolling shareholders (Ali, Chen, and Radhakrishnan, 2007), are called Type II agency problems. Ding et al. (2011) suggest that Type I agency problems in the family firms are similar to those in non-family firms in China, because they generally have the same concentrated ownership structure, while Type II agency problems in the family firms are more prominent than those in non-family firms, because "erosion" interests of controlling shareholders of non-family firms are dispersive and powerless, and the controlling shareholders of family firms are personal or their family. Which indicate that "erosion" interests are concentrated in family firms, so the owners of family firms have stronger motivations to occupy interests of minor shareholders. There have been many studies suggest that agency conflicts have impact on disclosure (see Healy \& Palepu, 2001, for a review), therefore, the difference of agency conflicts between SOEs and NSOEs will lead to the difference of their earnings quality. ${ }^{1}$

Bradshaw and Miller (2008) suggest that effective policy supervision is very crucial in the process to achieve the coordination results of accounting standards. The new CAS was issued in 2006 by The Finance Ministry of China, which mandated all listing corporation to carry out on January 1, 2007. It is a regulation and a part of legal system, which guarantees the effective implement of CAS in China. However, because the legal institutions which are designed to protect the rights of minority shareholders and may help to mitigate the differences of Type II agency problems between family and nonfamily firms are either nonexistent or ineffective in China (Allen, Qian, and Qian, 2005), in addition, accounting policy are selectable (e.g. it is selectable for whether the valuation of investment property adopts fair value accounting), so, the NSOEs are expected to prefer interests of big shareholders to better implementation of the new CAS. Moreover, besides the political and economic power, collectivism-oriented culture also strengthens the motivation to comply with standards (Xiao et al. 2004). The most important feature of China's company management system is a high degree of concentration in listed corporations, and generally, one shareholder can effectively control a corporation (Firth et al. 2007). Some of the dominant shareholders associate with state, while others associate with private investors. As has been noted, the selection of senior managers in SOEs is generally impacted by state to a certain degree. These senior management not only have responsibility to manage corporation, but have national administrative responsibility as well. Relative to SOEs, NSOEs are recent products of the country's economic reformation and opening-up policy, and the first group of entrepreneurs generally comprised farmers and workers who had been laid off as a result of the SOEs reforms (Ding et al., 2011). The collectivismorientated culture in NSOEs as operating unit under the market economy is not so strong compared to in SOEs. From the discussion above, NSOEs are supposed not to comply with the new CAS as strictly as SOEs, and it lead to the expected effect of new CAS in NSOEs may not be so obvious as in NSOEs.

H2a: value relevance of earnings would increase significantly after the adoption of IFRS in SOEs.

H2b: value relevance of earnings would not increase significantly after the adoption of IFRS in NSOES.

\section{METHODOLOGY, SAMPLE AND DESCRIPTIVE STATISTICS}

Following Barth et al. (2006), Lang, Raedy, \& Wilson (2006), and Liu et al. (2011) stock price denoted P is 6 months after fiscal year-end, and following Ding et al. (2011), RETURN represents cumulative market-adjusted return over the 12-months period from 8 months before the fiscal year-end to 4 months after it (from May 1 of year $\mathrm{t}$ to April 30 of year $t+1$, it is the earnings announcement period in China). As per Barth et al. (2006), we first regress $\mathrm{P}$ and RETURN on firm's Industrial Classification to obtain the residual $\mathrm{P} *$ and RETURN* which are unaffected by mean differences across industries for each period. Following Liu et al. (2011), we test value relevance with Equation 1 based on Ohlson's (1995) framework and Equation 2 based on Bartov, Goldberg, \& Kim (2005) model. In the Equations, the coefficient o interaction will show the changes of value relevance.

\footnotetext{
${ }^{1}$ According to $\mathrm{Xu}$ (2004), most companies have a controlling shareholder. In fact, in China, the ultimate controlling shareholders in some companies are state, and these companies are SOEs and non-family firms; while the ultimate controlling shareholders in the other companies are private, and these companies are NSEOs and family firms.
} 


$$
\begin{aligned}
& P_{i t}^{*}=\beta_{0}+\beta_{1} B P S_{i t}+\beta_{2} E P S_{i t}+\beta_{3} N C A S_{i t}+\beta_{4} B P S_{i t} \times N C A S_{i t}+\beta_{5} E P S_{i t} \times N C A S_{i t}+\varepsilon_{i t} \\
& \operatorname{RETURN}_{i t}^{*}=\beta_{0}+\beta_{1} E P S_{i t}+\beta_{2} N C A S_{i t}+\beta_{3} E P S_{i t} \times N C A S_{i t}+\varepsilon_{i t}
\end{aligned}
$$

Where BPS is book value per share; EPS is net income per share; NCAS is a dummy variable, which takes the value of 1 when the new CAS were adopted in our samples since 2007 to 2009 otherwise. In the regression (1) and (2), the main coefficient is that of $E P S \times N C A S$. If it is positive significantly, then value relevance of earnings is higher after the mandatory adoption of new CAS since 2007. A significantly negative coefficient would mean the opposite.

Table 1. Industry distribution of the companies

\begin{tabular}{l|r}
\hline \multicolumn{1}{c|}{ Industry } & Number \\
\hline Agriculture, forestry, animal husbandry and fishery & 10 \\
\hline Mining & 23 \\
\hline Manufacturing & 447 \\
\hline Electricity, heat, gas and water production and supply & 49 \\
\hline Construction & 17 \\
\hline Wholesale and Retail Trade & 95 \\
\hline Transportation, warehousing and postal service & 43 \\
\hline Hotels and Catering Services & 4 \\
\hline Information transmission, software and information technology & 18 \\
\hline Financial & 5 \\
\hline Real estate & 86 \\
\hline Leasing and Commercial Service & 8 \\
\hline Scientific research and technical services & 1 \\
\hline Water conservancy industry, the environment and public facilities & 10 \\
\hline The department of health and social work & 1 \\
\hline Culture, Sports and Entertainment & 5 \\
\hline Integration & 14 \\
\hline Total & 836 \\
\hline
\end{tabular}

Our samples aim at all companies listed on the motherboard market of A shares from 2004 to 2006, and the source of statements and stock price information is from the Wind database. We only select companies with no missing value in each period, and eliminate the extreme value of all the non dummy variables because metrics based on variability are sensitive to outliers (Christensen, Lee, \& Walker, 2015). The final samples consist of 836 companies including 568 SOEs and 268 NSOEs. In this paper, data are analyzed by STATA 12.0. The industry classification is follows the Industry Classification Standard issued by the Chinese Securities Regulatory Commission in 2012. The industry distribution of the sample companies is shown in Table 1, and the descriptive statistics of studied variables is shown in Table 2. 
Table 2. Descriptive Statistics

Panel A: Descriptive statistics for total sample

\begin{tabular}{l|c|c|c|c|c|c|c|c}
\hline & \multicolumn{9}{|c|}{$\mathbf{2 0 0 4 - 2 0 0 6}$} & \multicolumn{2}{c}{$\mathbf{2 0 0 7 - 2 0 0 9}$} \\
\hline Variable & Mean & Median & Std.dev & Obs. & Mean & Median & Std.dev & Obs. \\
\hline$B P S$ & 2.690 & 2.562 & 1.189 & 2508 & 2.866 & 2.646 & 1.435 & 2508 \\
\hline$E P S$ & 0.150 & 0.128 & 0.261 & 2508 & 0.219 & 0.170 & 0.317 & 2508 \\
\hline$P$ & 7.564 & 5.780 & 5.985 & 2508 & 9.215 & 7.805 & 5.088 & 2508 \\
\hline$R E T U R N$ & 0.556 & 0.030 & 1.236 & 2508 & 0.023 & -0.083 & 0.424 & 2508 \\
\hline
\end{tabular}

Panel B: Descriptive statistics for state-owned enterprises

\begin{tabular}{|c|c|c|c|c|c|c|c|c|}
\hline$B P S$ & 2.77 & 2.650 & 1.171 & 1704 & 3.055 & 2.850 & 1.430 & 1704 \\
\hline$E P S$ & 0.168 & 0.140 & 0.263 & 1704 & 0.231 & 0.183 & 0.321 & 1704 \\
\hline$P$ & 7.704 & 5.920 & 6.050 & 1704 & 9.421 & 7.980 & 5.172 & 1704 \\
\hline RETURN & 0.553 & 0.039 & 1.209 & 1704 & 0.016 & -0.077 & 0.411 & 1704 \\
\hline \multicolumn{9}{|c|}{ Panel C: Descriptive statistics for non state-owned enterprises } \\
\hline$B P S$ & 2.519 & 2.330 & 1.211 & 804 & 2.469 & 2.200 & 1.363 & 804 \\
\hline$E P S$ & 0.112 & 0.100 & 0.253 & 804 & 0.193 & 0.129 & 0.305 & 804 \\
\hline$P$ & 7.266 & 5.500 & 5.836 & 804 & 8.778 & 7.385 & 4.882 & 804 \\
\hline RETURN & 0.562 & 0.012 & 1.292 & 804 & 0.036 & -0.098 & 0.450 & 804 \\
\hline
\end{tabular}

\section{RESULTS}

Table 3 reports the estimation results based on total sample firms. The results of Price model measuring explanatory ability of accounting measurement on stock price shows value relevance of earnings is higher since 2007 . The coefficient of $E P S \times N C A S$ in equation 1 is 1.473 , and is significantly positive at the level of \%1; but the coefficient of $B P S \times N C A S$ is -0.364 , which is significantly negative at the level of $1 \%$. Therefore, the explanatory ability of earnings is increased significantly and the explanatory ability of book value is decreased significantly since 2007. Value relevance is estimated with Equation 2 that measures explanatory ability of accounting earnings on return. The coefficient of $E P S \times N C A S$ in equation 2 is 0.174 , which is significantly positive at the level of $1 \%$, it also indicates the explanatory ability of earnings is increased significantly since 2007 . So, value relevance of earnings is increased after the adoption of IFRS in 2007, which is consistent with the result of Liu et al. (2011).

Table 3. value relevance regression on all firms

\begin{tabular}{|c|c|c|c|c|}
\hline \multicolumn{5}{|c|}{ Panel A: Price model } \\
\hline \multicolumn{5}{|c|}{$P_{i t}^{*}=\beta_{0}+\beta_{1} B P S_{i t}+\beta_{2} E P S_{i t}+\beta_{3} N C A S_{i t}+\beta_{4} B P S_{i t} \times N C A S_{i t}+\beta_{5} E P S_{i t} \times N C A S_{i t}+\varepsilon_{i t}$} \\
\hline Variable & Coef. & Std. Err. & $\mathbf{t}$ & $\mathbf{p}$ \\
\hline Intercept & -2.720 & 0.223 & -12.17 & 0.000 \\
\hline$B P S$ & 0.707 & 0.084 & 8.43 & 0.000 \\
\hline$E P S$ & 5.446 & 0.383 & 14.23 & 0.000 \\
\hline$N C A S$ & 0.224 & 0.303 & 0.74 & 0.459 \\
\hline$B P S \times N C A S$ & -0.364 & 0.113 & -3.22 & 0.001 \\
\hline$E P S \times N C A S$ & 1.473 & 0.514 & 2.86 & 0.004 \\
\hline$N$ & 5016 & & & \\
\hline
\end{tabular}

Panel B: Return model

\begin{tabular}{l|c|c|c|c}
\hline \multicolumn{2}{c}{$R E T U R N_{i t}^{*}=\beta_{0}+\beta_{1} E P S_{i t}+\beta_{2} N C A S_{i t}+\beta_{3} E P S_{i t} \times N C A S_{i t}+\varepsilon_{i t}$} & \multicolumn{1}{c}{} \\
\hline \multicolumn{1}{c}{ Variable } & Coef. & Std. Err. & t & p \\
\hline Intercept & 0.016 & 0.012 & 1.34 & 0.180 \\
\hline EPS & -0.106 & 0.039 & -2.69 & 0.007 \\
\hline NCAS & -0.031 & 0.017 & -1.80 & 0.072 \\
\hline EPS $\times$ NCAS & 0.174 & 0.051 & 3.43 & 0.001 \\
\hline $\mathrm{N}$ & 5016 & & & \\
\hline
\end{tabular}


Table 4 presents the estimation results based on SOEs sample. The findings reveal higher value relevance of earnings since 2007, too. In equation 1, the coefficient of EPS $\times$ NCAS is 1.762 which is significantly positive at the level of $1 \%$, and the coefficient of BPS $\times$ NCAS is -0.339 which is significantly negative at the level of $5 \%$. It shows the higher explanatory ability of earnings and the lower explanatory ability of book value in state-owned enterprises since 2007. In equation 2 , the coefficient of EPS $\times$ NCAS is 0.248 which is significantly positive at level of 0.01 , and it means the explanatory of earnings increased significantly since 2007 . Hence, value relevance of earnings in stateowned enterprises is improved after adoption of IFRS in 2007.

Table 4. Value relevance regression on state-owned enterprises

\begin{tabular}{|c|c|c|c|c|}
\hline \multicolumn{5}{|c|}{ Panel A: Price model } \\
\hline \multicolumn{5}{|c|}{$P_{i t}^{*}=\beta_{0}+\beta_{1} B P S_{i t}+\beta_{2} E P S_{i t}+\beta_{3} N C A S_{i t}+\beta_{4} B P S_{i t} \times N C A S_{i t}+\beta_{5} E P S_{i t} \times N C A S_{i t}+\varepsilon_{i t}$} \\
\hline Variable & Coef. & Std. Err. & $t$ & $\mathbf{p}$ \\
\hline Intercept & -2.529 & 0.283 & -8.93 & 0.000 \\
\hline BPS & 0.635 & 0.104 & 6.12 & 0.000 \\
\hline EPS & 5.436 & 0.462 & 11.75 & 0.000 \\
\hline NCAS & 0.169 & 0.388 & 0.44 & 0.663 \\
\hline $\mathrm{BPS} \times \mathrm{NCAS}$ & -0.339 & 0.139 & -2.43 & 0.015 \\
\hline $\mathrm{EPS} \times \mathrm{NCAS}$ & 1.762 & 0.620 & 2.84 & 0.005 \\
\hline $\mathrm{N}$ & 3408 & & & \\
\hline
\end{tabular}

\begin{tabular}{|c|c|c|c|c|}
\hline \multicolumn{5}{|c|}{$\operatorname{RETURN}_{i t}^{*}=\beta_{0}+\beta_{1} E P S_{i t}+\beta_{2} N C A S_{i t}+\beta_{3} E P S_{i t} \times N C A S_{i t}+\varepsilon_{i t}$} \\
\hline Variable & Coef. & Std. Err. & $\mathbf{t}$ & $\mathbf{p}$ \\
\hline Intercept & 0.023 & 0.014 & 1.65 & 0.099 \\
\hline EPS & -0.156 & 0.046 & -3.42 & 0.001 \\
\hline NCAS & -0.052 & 0.021 & -2.52 & 0.012 \\
\hline $\mathrm{EPS} \times \mathrm{NCAS}$ & 0.248 & 0.059 & 4.21 & 0.000 \\
\hline $\mathrm{N}$ & 3408 & & & \\
\hline
\end{tabular}

Table 5 shows the results of regression on value relevance based on the samples of NSOEs, which are different from the results in SOEs samples. In equation 1, coefficient of BPS $\times$ NCAS variable is -0.439 which is significantly negative at level of $5 \%$, and coefficient of EPS $\times$ NCAS is positive, but it is not significantly. It means value relevance of book value decreased and value relevance of earnings has no significant changes since 2007. In equation2, coefficient of EPS $\times$ NCAS is not significant, too. So, the findings show value relevance of accounting measures decreased in private enterprises after adoption of IFRS in 2007, for value relevance of book value decreased significantly.

The empirical study shows the significantly higher value relevance of earnings after the mandatory adoption of the new CAS convergent with IFRS in 2007 in China. Because of the difference in Type II agency problems and the different motivation on applying the new CAS in SOEs and NSOEs, the changes of value relevance of earnings are different in SOEs and NSOEs after the mandatory adoption of the new CAS, i.e., value relevance of earnings of SOEs has improved significantly, while value relevance of earnings of NSOEss has no significant change. In summary, either analyzing all enterprises or only analyzing SOEs, we find that earnings quality is improved significantly, but, which is different from the results of Liu et al. (2007). As per Barth, Lnadsman, \& Lang (2008), the higher accounting quality of accounting shows in the improvement of value relevance of earnings and book value, although this study finds that the explanatory power of earnings on stock price and returns increased in SOEs, the explanatory power of book value on stock price decreased. The improvement of accounting quality in SOEs is questionable. 
Table 5. Value relevance regression on private enterprises

\begin{tabular}{|c|c|c|c|c|}
\hline \multicolumn{5}{|c|}{ Panel A: Price model } \\
\hline \multicolumn{5}{|c|}{$P_{i t}^{*}=\beta_{0}+\beta_{1} B P S_{i t}+\beta_{2} E P S_{i t}+\beta_{3} N C A S_{i t}+\beta_{4} B P S_{i t} \times N C A S_{i t}+\beta_{5} E P S_{i t} \times N C A S_{i t}+\varepsilon_{i t}$} \\
\hline Variable & Coef. & Std. Err. & $\mathbf{t}$ & $\mathbf{p}$ \\
\hline Intercept & -3.066 & 0.364 & -8.43 & 0.000 \\
\hline BPS & 0.852 & 0.143 & 5.96 & 0.000 \\
\hline EPS & 5.491 & 0.687 & 8.00 & 0.000 \\
\hline NCAS & 0.395 & 0.489 & 0.81 & 0.419 \\
\hline $\mathrm{BPS} \times \mathrm{NCAS}$ & -0.439 & 0.200 & -2.19 & 0.029 \\
\hline $\mathrm{EPS} \times \mathrm{NCAS}$ & 0.820 & 0.929 & 0.88 & 0.377 \\
\hline $\mathrm{N}$ & 1608 & & & \\
\hline \multicolumn{5}{|c|}{ Panel B: Return model } \\
\hline \multicolumn{5}{|c|}{$\operatorname{RETURN}_{i t}^{*}=\beta_{0}+\beta_{1} E P S_{i t}+\beta_{2} N C A S_{i t}+\beta_{3} E P S_{i t} \times N C A S_{i t}+\varepsilon_{i t}$} \\
\hline Variable & Coef. & Std. Err. & $\mathbf{t}$ & $\mathbf{p}$ \\
\hline Intercept & 0.005 & 0.021 & 0.21 & 0.831 \\
\hline EPS & 0.012 & 0.077 & 0.15 & 0.879 \\
\hline NCAS & 0.006 & 0.031 & 0.20 & 0.839 \\
\hline $\mathrm{EPS} \times \mathrm{NCAS}$ & 0.009 & 0.099 & 0.09 & 0.932 \\
\hline $\mathrm{N}$ & 1608 & & & \\
\hline
\end{tabular}

In order to control the impact of time trend, we use the modified Price Model and Return Model, and add the time variable denoted as Year and the industry variable denoted as Industry as the control variables, and Table 6 shows almost the same empirical results consistent with the above findings, except for the higher significance of $E P S \times N C A S$ in Price Model based on samples of total firms is at the level $10 \%$ compared to the above findings at the level of $1 \%$. As a sensitivity test, we add the outliers, and rerun the regression (1) and (2) based on the samples including the outliers, and reach the same results as the above ones except for the lower adjusted R-square. In addition, we reach the same conclusions by excluding the excluding extraordinary items in EPS variable. The conclusions of our regression are robust.

Table 6. Regressions with time variable.

\begin{tabular}{|c|c|c|c|c|c|c|}
\hline \multicolumn{7}{|c|}{ Panel A: Price Model } \\
\hline \multicolumn{7}{|c|}{$\begin{array}{l}P_{i t}=\beta_{0}+\beta_{1} B P S_{i t}+\beta_{2} E P S_{i t}+\beta_{3} N C A S_{i t}+\beta_{4} B P S_{i t} \times N C A S_{i t}+\beta_{5} E P S_{i t} \times N C A S_{i t} \\
+\beta_{6} \text { Industry }+\beta_{7} \text { Year }+\varepsilon_{i t}\end{array}$} \\
\hline & \multicolumn{2}{|c|}{ All firms } & \multicolumn{2}{|c|}{ SOES } & \multicolumn{2}{|c|}{ NSOES } \\
\hline Variable & Coef. & t-state & Coef. & t-state & Coef. & t-state \\
\hline Intercept & -0.034 & -0.11 & 0.005 & 0.01 & -0.119 & -0.23 \\
\hline$B P S$ & $0.588 * * *$ & 6.60 & $0.561 * * *$ & 5.08 & $0.639 * * *$ & 4.23 \\
\hline$E P S$ & $6.082 * * *$ & 15.02 & $5.908 * * *$ & 12.03 & $6.506^{* * *}$ & 9.03 \\
\hline$N C A S$ & $-5.774 * * *$ & -14.62 & $-5.681 * * *$ & -11.34 & $-5.926 * * *$ & -9.15 \\
\hline$B P S \times N C A S$ & $-0.271 * *$ & -2.26 & $-0.319 * *$ & -2.16 & -0.188 & -0.89 \\
\hline$E P S \times N C A S$ & $1.007^{*}$ & 1.85 & $1.539 * *$ & 2.33 & -0.215 & -0.22 \\
\hline Indrstry & Yes & & Yes & & Yes & 0.48 \\
\hline Year & Yes & & Yes & & Yes & \\
\hline$N$ & 5016 & & 3408 & & 1608 & \\
\hline
\end{tabular}

(Table 6 continued on next page) 
(Table 6 continued)

\begin{tabular}{|c|c|c|c|c|c|c|}
\hline \multicolumn{7}{|c|}{ Panel B: Return Model } \\
\hline \multicolumn{7}{|c|}{$\operatorname{RETURN}_{i t}=\beta_{0}+\beta_{1} \operatorname{EPS}_{i t}+\beta_{2} N C A S_{i t}+\beta_{3} E P S_{i t} \times N C A S_{i t}+\beta_{4}$ Industry $+\beta_{5}$ Year $+\varepsilon_{i t}$} \\
\hline & \multicolumn{2}{|c|}{ All firms } & \multicolumn{2}{|c|}{ SOEs } & \multicolumn{2}{|c|}{ NSOES } \\
\hline Variable & Coef. & t-state & Coef. & t-state & Coef. & t-state \\
\hline Intercept & $-0.912 * * *$ & -27.98 & $-0.874 * * *$ & -22.56 & $-0.990 * * *$ & -16.56 \\
\hline EPS & 0.009 & 0.18 & -0.054 & -0.86 & 0.167 & 1.63 \\
\hline$N C A S$ & $-2.799 * * *$ & -64.38 & $-2.773 * * *$ & -53.35 & $-2.865 * * *$ & -36.21 \\
\hline$E P S \times N C A S$ & $0.197 * * *$ & 2.84 & $0.286^{* * *}$ & 3.51 & -0.013 & -0.10 \\
\hline Industry & Yes & & Yes & & Yes & \\
\hline Year & Yes & & Yes & & Yes & \\
\hline$N$ & 5016 & & 3408 & & 1608 & \\
\hline
\end{tabular}

Note: *** indicates a significance level of $1 \%, * *$ indicates a significance level of $5 \%$, indicates a significance level of $10 \%$.

\section{CONCLUSION}

As the largest and the most rapid developing emerging market, China is becoming more and more important to investors around the world (Lin and Liu, 2009), China is also a very important area for testing the importance of IFRS (Liu et al., 2011). This paper tests the changes in value relevance of earnings, as well as the different changes of value relevance of earnings between SOEs and NSOEs after the mandatory adoption of the new CAS which is substantially convergent with IFRS in 2007. Empirical results show that value relevance of earnings increased significantly in China's listed enterprises after 2007. It indicates that the new CAS convergent with IFRS improves earnings quality of China's listed corporations. However, due to the unique characteristics of China's economy, SOEs dominated in the capital market, meanwhile NSOEs developed rapidly, and SOEs have more obvious collectivistic characteristics than NSOEs because of their different historical background. In addition, under the same legal and cultural environment, NSOEs have the same level of Type I agency problems as SOEs, but they have more serious Type II agency problems than the SOEs. So, the effect of the implementation of new CAS on SOEs and NSOEs is different. Empirical results show that the value relevance of earnings of state-owned enterprises has improved significantly while the value relevance of earnings of private enterprises has no significant changes after adoption of the new CAS.

There are several limitations in this paper. Firstly, this paper focuses on the changes of the value relevance of earnings, and we do not explain the lower value relevance of book value after the adoption of the new CAS, so, future researches could study this phenomenon from more perspectives by analyzing characteristic of China's economy, institution, culture and corporate governance. Secondly, the paper only tests earnings quality with value relevance of earnings, and the future researches can study earnings quality with other dimensions, such as informativeness of earnings and accounting conservatism, and can research whether China reaches other expected advantages from adoption of IFRS, such as a lower cost of capital and the attraction of more foreign investments.

\section{ACKNOWLEDGEMENT}

The main contents of this paper has been posted at 2014 AAA annual meeting and the authors are grateful to the invaluable remarks and suggestions from participants.

\section{AUTHOR BIOGRAPHIES}

Hong Guo was born in Shangqiu city, Henan Province, China, in 1979. She received MS degree from Xi'an Jiaotong University, Xi'an, China, in 2006. Currently, she is a Ph.D candidate at Xi'an Jiaotong University. She focuses on accounting theory. Email: guoxm320@163.com

Wanli Li was born in Xi'an city, Shaanxi Province, China, in 1963. She received Ph. D degree from Xi'an Jiaotong University, Xi'an, China, in 2003. Currently, she is a professor at Xi'an Jiaotong University. She focuses on accounting theory. Email: lwlxjtu@126.com 


\section{REFERENCES}

Ali, A., Chen, T. Y., \& Radhakrishnan, S. (2007). "Corporate disclosures by family firms". Journal of Accounting and Economics, 44(1-2) 238-286.

Allen, F., Qian, J., \& Qian, M. (2005). "Law, finance, and economic growth in China”. Journal of Financial Economics, 77(1) 57-116.

Barth, M., Landsman, W., Lang, M. (2008). "International accounting standards and accounting quality". Journal of Accounting Research, 46(3)467-498.

Barth, M., Landsman, W., Lang, M., \& Williams, C. (2006). “Accounting quality: International accounting standards and U.S. GAAP”, Working paper, Stanford University and University of North Carolina, Stanford, March.

Bartov, E., Goldberg, S., \& Kim, M. (2005). "Comparative value relevance among German, U.S., and international accounting standards: A German stock market perspective". Journal of Accounting, Auditing \& Finance, 20(2) 95-119.

Bradshaw, M. T., \& Miller, G. S. (2008). "Will harmonizing accounting standards really harmonize accounting? Evidence from Non-US-firms adopting U.S. GAAP”. Journal of Accounting, Auditing \& Finance, 23(2) 233-263.

Bushman, R., \& Landsman, W. R. (2010). "The pros and cons of regulating corporate reporting: A critical review of the arguments. Accounting and Business Research, 40(3) 259-273.

Capkun, V., Cazavan-Jeny, A., Jeanjean, T., \& Weiss, L. A. (2008). "Earnings management and value relevance during the mandatory transition from local GAAPs to IFRS in Europe", Working paper, HEC, ESSEC and Georgetown University, Paris, France and Medford, 25 April.

Chamisa, E. E. (2010). "The relevance and observance of the IASC standards in developing countries and the particular case of Zimbabwe". International Journal of Accounting, 35(2) 267-286.

Christensen, H. B., Lee, E., \& Walker, M. (2015). "Incentives or standards: What determines accounting quality changes around IFRS adoption?" European Accounting Review, 24(1) 31-61

Chua, W. F., \& Taylor, S. L. (2008). "The rise and rise of IFRS: An examination of IFRS diffusion”. Journal of Accounting and Public Policy, 27(6) 462-473.

Clarkson, P., Hanna, J., Richardson, G., \& Thompson, R. (2011). "The impact of IFRS adoption on the value relevance of book value and earnings". Journal of Contemporary Accounting and Economics, 7(1) 1-17.

Cormier, D., Demaria, S., Lapointe-Antunes, P., \& Teller, R. (2009). "First-time adoption of IFRS, managerial incentives, and value-relevance: Some French evidence". Journal of International Accounting Research, 8(2) 1-22.

Daske, H., Hail, L., Leuz, C., \& Verdi, R. (2008). "Mandatory IFRS reporting around the world: Early evidence on the economic consequences". Journal of Accounting Research, 46(5) 1085-1142.

Ding, S. J., Qu, B. Z., \& Zhuang, Z. Li. (2011). “Accounting Properties of Chinese Family Firms”. Journal of Accounting, Auditing \& Finance, 26(4) 623-640.

Ding, Y., \& Su, X. (2008). "Implementation of IFRS in a regulated market". Journal of Accounting and Public Policy, 27(6) 474479.

Firth, M., Fung, P., \& Rui, O. (2007). "Ownership, two-tier board structure, and the informativeness of earnings-Evidence from China". Journal of Accounting and Public Policy, 26(4) 463-496.

Gjerde, O., Knivsfla, K. H., \& Saettan, F. (2008). "The value relevance of adopting IFRS: Evidence from 145 NGAAP restatements". Journal of International Accounting, Auditing and Taxation, 17(2) 92-112.

Goodwin, J., Ahmed, K., \& Heaney R. (2007). "Are components of reconciliations to international financial reporting standards useful to investors?" Working paper, 2007 AFAANZ Conference.

He, X. J., Wong, T. J., \& Young, D. Q. (2012). “Challenges for Implementation of Fair Value Accounting in Emerging Markets: Evidence from China". Contemporary Accounting Research, 29(2) 538-562.

Healy, P., \& Palepu, K. (2001). "Information asymmetry, corporate disclosure, and the capital markets: A review of the empirical disclosure literature". Journal of Accounting and Economics, 31(1-3) 405-440.

Horton, J., \& Serafeim, G. (2010). "Market reaction \& valuation of IFRS reconciliation adjustments: First evidence from UK". Review of Accounting Studies, 15(4) 725-751.

Jeanjean, T., \& Stolowy, H. (2008). "Do accounting standards matter? An exploratory analysis of earnings management before and after IFRS adoption”. Journal of Accounting and Public Policy, 27(6) 480-494.

Jenson, M., \& Meckling, W. (1976). "Theory of the firm: Managerial behavior, agency costs and ownership structure". Journal of Financial Economics, 3(4)305-360.

Jermakowicz, E. K., Prather-Kinsey, J., \& Wulf, I. (2007). “The value relevance of accounting income reported by DAX-30 German companies". Journal of International Financial Management and Accounting, 18(3) 151-191.

Lang, M., Raedy, J., \& Wilson, W. (2006). "Earnings management and cross-listing: Are reconciled earnings comparable to U.S. earnings?" Journal of Accounting and Economics, 42(1-2) 255-283.

Li, S. (2010). "Does mandatory adoption of international financial reporting standards in the European Union reduce the cost of equity capital?” The Accounting Review, 85(2) 607-636

Lin, Z. J., \& Liu, M. (2009). "The impact of corporate governance on auditor choice: Evidence from China”. Journal of International Accounting, Auditing and Taxation, 18(1) 44-59.

Liu, C. H., Yao, Lee. J., Hu, N., \& Liu, L. (2011). “The impact of IFRS on Accounting Quality in a Regulated Market: An 
Empirical Study of China". Journal of Accounting, Auditing \& Finance, 26(4) 659-676.

Morck, R., Shleifer, A., \& Vishney, R W. (1989). “Alternate mechanisms for corporate control”. American Economic Review, 79(4) 842-852.

Ohlson, J. A. (1995). "Earnings, book value, and dividends in security valuation”. Contemporary Accounting Research, 11(2) 661-687.

Shleifer, A., \& Vishny, R. (1986). "Large shareholders and corporate control”. Journal of Political Economy, 94(3) 461-488.

Soderstrom, N. S., \& Sun, K. J. (2007). "IFRS adoption and accounting quality: A review”. European Accounting Review, 16(4) $675-702$.

Sunder, S. (2009). "IFRS and the accounting consensus". Accounting Horizons, 23(1) 101-111.

Tan, J., Yang, J., \& Veliyath, R. (2009). "Particularistic and system trust among small and medium enterprises: A comparative study in China's transition economy". Journal of Business Venturing, 24(6) 544-557.

Tirole, J., 2001. "Corporate governance". Econometrica, 69(1) 1-35.

Tyrrall, D., Woodward, D., \& Rakhimbekova, A. (2007). "The relevance of international financial reporting standards to a developing country: Evidence from Kazakhstan". International Journal of Accounting, 42(1) 82-110.

Wu, J., Boateng, A., \& Drury, C. (2007). "An analysis of the adoption, perceived benefits, and expected future emphasis of western management accounting practices in Chinese SOEs and JVs". International Journal of Accounting, 42(2) 171185.

Wu, J. S., \& Zhang, I. X. (2010). “Accounting integration and comparability: Evidence from relative performance evaluation around IFRS adoption", Working paper, University of Rochester and University of Minnesota, Twin Cities, 30 July.

Xiao, J. Z., Weetman, P., \& Sun, M. (2004). "Political influence and coexistence of a uniform accounting system and accounting standards: Recent developments in China". Abacus, 40(2) 193-218.

$\mathrm{Xu}$, L. (2004). "Types of large shareholders, corporate governance and firm performance: Evidence from China's listed companies", Working paper, Hong Kong Polytechnic University.

Yip, W., and D. Young. (2012). "Does mandatory IFRS adoption improve information comparability?". The Accounting Review, 87(5) 1767-1789. 